\title{
FOOD HABITS OF CHECKERED KEELBACK, XENOCHROPHIS PISCATOR (SCHNEIDER, 1799), IN BANGLADESH
}

\author{
Md. Lokman Hossain* \\ Department of Zoology, Dhaka College, Dhaka 1205, Bangladesh
}

\begin{abstract}
Checkered Keelback, Xenochrophis piscator, was found to inhabit aquatic, semi-aquatic, terrestrial and fossorial habitats. The average body weight of Checkered Keelback was $233 \pm 107.25 \mathrm{~g}$. The average weight of the consumed food by each animal was $10.28 \pm 6.78 \mathrm{~g}$, which was $4.41 \%$ of their body weight. A total of 23 food items were found in the stomachs of 40 snakes. All the food items were animal food, but three categories of accidental food items were found in the stomachs. Based on food contents the snake fed mainly on arthropods (56.52\%), fish $(26.80 \%)$ and amphibians (17.39\%). The consumption of food varied seasonally, being much less in winter compared to summer and rainy seasons but the per cent frequency of occurrence of insects in relation to the total number of food items was more or less the same in all seasons. Insects belonged to 14 families under seven orders, mostly harmful to agriculture, fish ponds, gardens and human residences.
\end{abstract}

Key words: Food habits, Checkered Keelback, Bangladesh

\section{INTRODUCTION}

Checkered Keelback, Xenochrophis piscator, or locally known as Dhora sap is found in or near freshwater lakes or rivers. It plays an important role in the ecosystem by feeding on a variety of invertebrate and small vertebrate animals and thus controls the ecological balance (Rao and Cherian 1940). The snake feeds mainly on small fishes and water frogs. They are economically important as major predators of insects (Wadeker 1963) and they consume mainly invertebrates (Pough et al. 2001). Due to habitat destruction and food scarcity the population is declining day by day (Sanil and Andrews 1995). McCann (1933) reported that insects damage the paddy crop and hence the snake should be considered as natural controlling agents of insects harmful to agriculture. Orthopteran species were available food items of Checkered Keelback during the major part of the year (Issac and Rege 1975). The snakes consumed large amount of nymphs of grasshoppers in the rice field and thus acted as one of the natural controlling agents of rice grasshoppers and they prey during day and night.

Some works have been conducted on food habits of Checkered Keelback in different countries including Bangladesh by Wadekar (1963), Khan (1973), Dutta

*Author for correspondence: E-mail : drlokmanhossain@yahoo.com

(C) 2016 Zoological Society of Bangladesh DOI: 10.3329/bjz.v44i1.30185 
(1976), Fugler (1982), Daniel (1983), Joshee (1986), Raj et al. (2005), Ahsan (1983). The present study deals with the seasonal variation of the food habits of Checkered Keelback. This study has been an attempt to determine the food habits and habitat. The findings will help the researchers to assess the contribution of the species to maintain ecological balance.

\section{MATERIAL AND METHODS}

A total of 40 Checkered Keelback was collected from the natural habitats to assess the qualitative and quantitative information on their food habits. The specimens were captured mainly at midnight from fish ponds, canals, open fields, agriculture fields, and were anesthetized instantly for measuring their total body weight. The stomachs of the snakes were dissected out in the field with food contents and then preserved in airtight container. The consumed food was separated item wise by incising the stomachs longitudinally and preserved separately. A solution of $5 \%$ formalin and $1 \%$ glycerin was used as preservative. The stomach contents were weighed and examined under binocular microscope for qualitative analysis of food items. The stomach contents of each individual were categorized into groups: (a) animals up to species level and (b) accidental particles. Identification was made by consulting books, guides (Daniel 1983, Borror and Delong 1981, Imms 1965) and relevant specialists. Stomach contents of individual snakes were analyzed as quantitative according to Hartley (1948).

Food consumption was calculated month-wise and subsequently seasonwise and converted to percentage in relation to body weight. Regression analysis was made between body weight and consumed food and also made Chi-square test was done for seasonal difference. The monthly food consumption was also studied in all the three seasons throughout the study period to ascertain the seasonal difference. Frequency of occurrence of food items was recorded. For convenience, the study period was divided into three seasons: Summer (MarchJune), Monsoon (July-October) and Winter (November-February). Of the snakes, 9 specimens were captured in summer, 18 in monsoon and 13 in winter seasons. The frequency of every food item was transformed into percent frequency of occurrence in two ways: firstly, calculation was made in relation to total number of food items found in the total number of stomachs and secondly, in relation to the total amount of food contents found in the stomachs studied.

The stomach contents were analyzed through qualitative and quantitative methods. At least two stomachs were collected in each month and separated the consumed food items for the study of food preferences. 


\section{RESULTS AND DISCUSSION}

In the present study the Checkered Keelback was found to inhabit aquatic, semi-aquatic, terrestrial and fosorial, burrial habitats i.e., fish ponds, derelict ponds, ditches, canals, streams, marshy areas, paddy fields, along with decomposed aquatic weeds, bank of waterbodies, along the road sides towards the nearest sources of water. The findings on food habits are as follows-

A total of 23 food items were identified in the 40 stomach contents. The snake has been identified as carnivore as because all the food items found in the stomach contents were aquatic, semi-aquatic and terrestrial animals and animal fragments (Table 1$)$. The major food items were insects $(56.52 \%)$, fish $(26.08 \%)$ and amphibians (17.39\%). Insects seem to be the major portion of their diet. Daniel (1993) stated that the snakes preferred animal foods i.e., it fed on adult frogs, fish, insect in nature. Khan (1992) mentioned that Checkered Keelback mainly feeds on frogs and toads. They are active both day and night and feeds on fish, frogs, occationally rodents, birds, tadepole and aquatic insects (Ahsan 1983).

Body weight of 40 snakes weighing 60 to $620 \mathrm{~g}$ (average $233 \pm 107.24 \mathrm{~g}$ ), were studied and found that the average weight of the consumed food of each snake was $10.28 \pm 6.78 \mathrm{~g}$. The amount of food in the stomach collected in different months of the year showed that the consumption was much lower during winter months, than the rainy and summer months (Figs 2 and 3).

The weight of consumed food was much lower during winter months $(6.4 \pm$ $2.63 \mathrm{~g}$ ) and that was $2.41 \%$ in relation to average body weight. Of the total 23 food items were indentified among which $100 \%$ were as animal foods. Arthropods constituted $49.81 \%$ of the food. Other than insects, small fishes, small amphibians and other accidental foods were found in their stomachs which covered $50.19 \%$ (Table 1 ).

The consumption of insects by the snakes was very high throughout the year (Fig. 1). Insects were found in each of the 40 stomach contents. The amount of food items found in each stomach varied from 0.1 to $23 \mathrm{~g}$ (mean was $10.28 \pm$ $6.78 \mathrm{~g}$ ). The mean weight of dissected snakes was $233 \pm 107.24 \mathrm{~g}$ (range 60 and $620 \mathrm{~g})$.

The food consumption was $4.41 \%$ in relation to mean body weight of the dissected snakes. The highest frequency of food items were grasshopper, Melanoplus differntialis (8.74\%) and the least consumed food item was Climbing perch $(0.35 \%)$. Insects was found almost in all the stomachs $(n=36)$ and only o1stomach contained the climbing perch (Table 1). 
Table 1. Food items from the stomachs of Checkered Keelback

\begin{tabular}{|c|c|c|c|c|c|}
\hline Classified food items & $\begin{array}{l}\text { Group } \\
\text { (Order and family) }\end{array}$ & $\begin{array}{c}\text { Frequency } \\
\text { of } \\
\text { occurrence } \\
\text { (no.) }\end{array}$ & $\begin{array}{c}\text { Frequency } \\
\text { of } \\
\text { occurrence } \\
(\%)\end{array}$ & $\begin{array}{l}\text { Total wt. of } \\
\text { stomach } \\
\text { contents } \\
\text { (g) }\end{array}$ & $\begin{array}{c}\text { Occurrence } \\
\text { relation to } \\
\text { consumed } \\
\text { food (\%) }\end{array}$ \\
\hline $\begin{array}{l}\text { Telapia' fish } \\
\text { Telapia mosambica }\end{array}$ & $\begin{array}{l}\text { O-Cypriniformes } \\
\text { F-Cyprinidae }\end{array}$ & 13 & 32.5 & 53.0 & 12.90 \\
\hline $\begin{array}{l}\text { Punti' fish } \\
\text { Puntius spp. }\end{array}$ & $\begin{array}{l}\text { O-Cypriniformes } \\
\text { F-Cyprinidae }\end{array}$ & 21 & 52.5 & 33.0 & 08.03 \\
\hline $\begin{array}{l}\text { Mola' fish, } \\
\text { Amblyphrayngodon mola }\end{array}$ & $\begin{array}{l}\text { O-Cypriniformes } \\
\text { F-Cyprinidae }\end{array}$ & 12 & 30.0 & 8.0 & 1.95 \\
\hline $\begin{array}{l}\text { 'Bale’ fish } \\
\text { Glossogobinus giuris }\end{array}$ & $\begin{array}{l}\text { O-Perciformes } \\
\text { F-Gobiidae }\end{array}$ & 7 & 17.5 & 18.5 & 04.50 \\
\hline $\begin{array}{l}\text { Climing perch, } \\
\text { Anabus testudineus }\end{array}$ & $\begin{array}{l}\text { O-Perciformes } \\
\text { F-Anabantidae }\end{array}$ & 1 & 2.5 & 43.0 & 10.46 \\
\hline $\begin{array}{l}\text { 'Taki fish' } \\
\text { Channa punctatus }\end{array}$ & $\begin{array}{l}\text { O-Channiformes } \\
\text { F- Channidae }\end{array}$ & 7 & 17.5 & 42.5 & 10.34 \\
\hline Tadpole larvae & $\begin{array}{l}\text { O-Anura } \\
\text { F-Discroglossidae }\end{array}$ & 8 & 20.0 & 8.0 & 1.95 \\
\hline $\begin{array}{l}\text { Common Skittering Frogs } \\
\text { Euphylyctis cyanophlyctis }\end{array}$ & $\begin{array}{l}\text { O-Anura } \\
\text { F-Discroglossidae }\end{array}$ & 8 & 20.0 & 20.5 & 4.99 \\
\hline $\begin{array}{l}\text { Indian Bull Frog } \\
\text { Hoplobactrachus tigerinus }\end{array}$ & $\begin{array}{l}\text { O-Anura } \\
\text { F- Discroglossidae }\end{array}$ & 2 & 5.0 & 21.0 & 5.11 \\
\hline $\begin{array}{l}\text { Common Toad, } \\
\text { Dattaphrynus melanostictus }\end{array}$ & $\begin{array}{l}\text { O-Anura } \\
\text { F-Bufonidae }\end{array}$ & 5 & 12.5 & 22.5 & 5.47 \\
\hline $\begin{array}{l}\text { Freshwater prawn, } \\
\text { Macrobrachium spp. }\end{array}$ & $\begin{array}{l}\text { O-Crustacea } \\
\text { F-Palaemonidae }\end{array}$ & 17 & 42.5 & 19.5 & 4.74 \\
\hline $\begin{array}{l}\text { Passalids beetle, } \\
\text { Passalus cornutus }\end{array}$ & $\begin{array}{l}\text { O-Coloeptera } \\
\text { F-Passalidae }\end{array}$ & 29 & 72.5 & 9.0 & 2.19 \\
\hline $\begin{array}{l}\text { Hermit flower beetle, } \\
\text { Osmoderma eremicola }\end{array}$ & $\begin{array}{l}\text { O-Coloeptera } \\
\text { F-Scarabaeidae }\end{array}$ & 9 & 22.5 & 11.5 & 2.80 \\
\hline $\begin{array}{l}\text { Rhinoceros beetle, } \\
\text { Dynastes tityus }\end{array}$ & $\begin{array}{l}\text { O-Coloeptera } \\
\text { F-Scarabaeidae }\end{array}$ & 3 & 7.5 & 8.5 & 2.07 \\
\hline $\begin{array}{l}\text { Ground spider, } \\
\text { Lycosa sp. }\end{array}$ & $\begin{array}{l}\text { O-Araneida } \\
\text { F-Pisauridae }\end{array}$ & 15 & 37.5 & 10.5 & 2.55 \\
\hline $\begin{array}{l}\text { Trogid beetle, } \\
\text { Geotrupes splendidus }\end{array}$ & $\begin{array}{l}\text { O-Coloeptera } \\
\text { F-Scarabaeidae }\end{array}$ & 19 & 47.5 & 9.5 & 2.31 \\
\hline $\begin{array}{l}\text { Dung beetle, } \\
\text { Phanaeus carnifex }\end{array}$ & $\begin{array}{l}\text { O-Coloeptera } \\
\text { F-Scarabaeidae }\end{array}$ & 10 & 25.0 & 12.0 & 2.92 \\
\hline $\begin{array}{l}\text { Long horned wood boring } \\
\text { beetle, Goes tigrinus }\end{array}$ & $\begin{array}{l}\text { O-Coloeptera } \\
\text { F-Cerambycidae }\end{array}$ & 12 & 30.0 & 9.0 & 2.19 \\
\hline $\begin{array}{l}\text { Dragonfly, } \\
\text { Argia emma }\end{array}$ & $\begin{array}{l}\text { O-Odonata } \\
\text { F-Coenagriondae }\end{array}$ & 23 & 57.5 & 6.5 & 1.58 \\
\hline $\begin{array}{l}\text { Grasshopper, } \\
\text { Melanoplus differntialis }\end{array}$ & $\begin{array}{l}\text { O-Orthoptera } \\
\text { F-Acridae }\end{array}$ & 25 & 62.5 & 8.5 & 2.07 \\
\hline $\begin{array}{l}\text { Creeping water bug, } \\
\text { Pelocoris femoratus }\end{array}$ & $\begin{array}{l}\text { O-Hemiptera } \\
\text { F-Naucoridae }\end{array}$ & 13 & 32.5 & 18.5 & 4.50 \\
\hline $\begin{array}{l}\text { Water scorpion, } \\
\text { Ranatra fusca }\end{array}$ & $\begin{array}{l}\text { O-Hemiptera } \\
\text { F-Notonectidae }\end{array}$ & 11 & 27.5 & 12.5 & 3.04 \\
\hline $\begin{array}{l}\text { Butterflies, } \\
\text { Nymphalis sp. }\end{array}$ & $\begin{array}{l}\text { O-Lepidoptera } \\
\text { F-Nymphalidae }\end{array}$ & 17 & 42.5 & 5.5 & 1.34 \\
\hline
\end{tabular}

During the summer, 9 stomachs were analyzed and identified 13 food items. The weight of stomach contents was $141.9 \mathrm{~g}$ and the mean weight of the snakes 
was $242.22 \pm 54.83 \mathrm{~g}$. Of the food items, grasshopper was common and found in $09(100 \%)$ stomachs and tadepole was in $4(25 \%)$ stomachs. The food consumption varied from 1.3 to $23 \mathrm{~g}$ (mean $15.77 \pm 6.73 \mathrm{~g}$ ). This consumption was $6.51 \%$ in relation to the mean body weight.

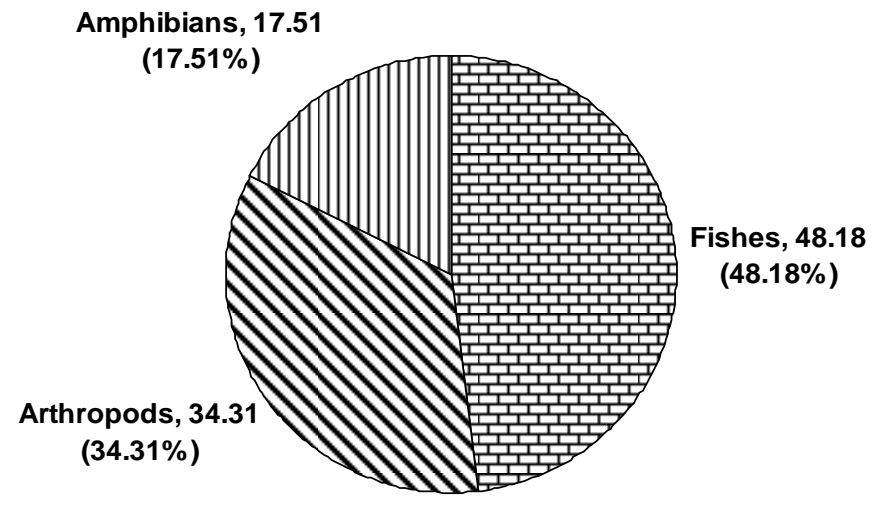

Fig. 1. Food items found in the stomachs of Checkered Keelback.

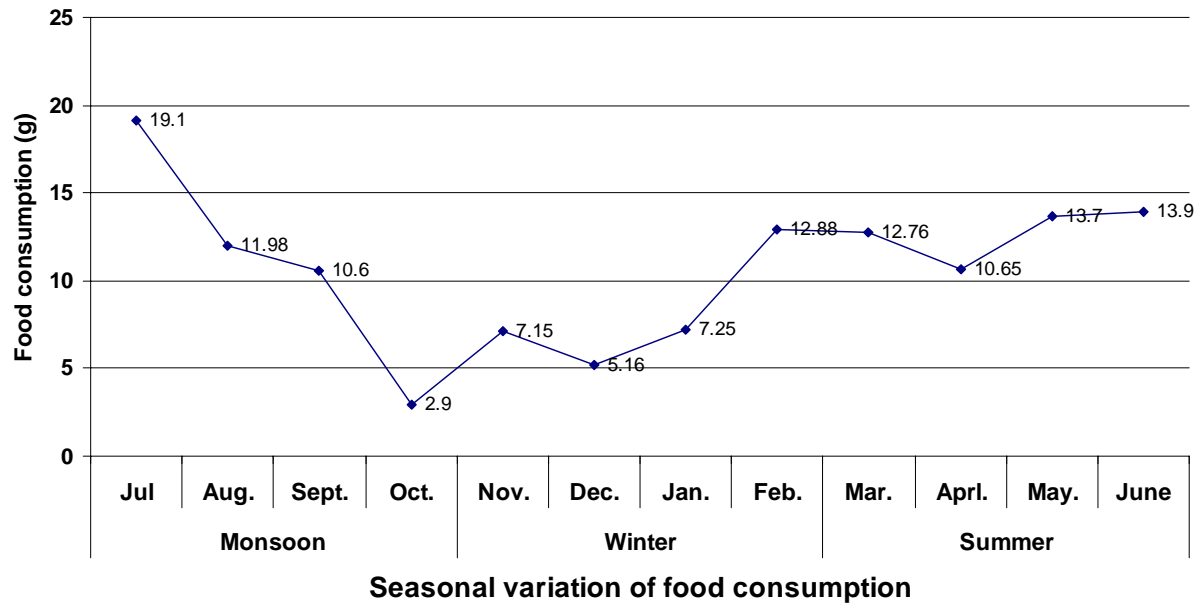

Fig. 2. Seasonal variation of food consumption by Checkered Keelback.

In the monsoon, 18 stomachs were analyzed and identified 16 food items. The weight of stomach contents was $186.4 \mathrm{~g}$ and the mean weight of the snake was $238.05 \pm 13.78 \mathrm{~g}$. Of the food items, Melanoplus differntialis was common and found in all the stomach contents. The least number of food items was fishes and frogs that were found only in $5(27.78 \%)$ stomachs. The food consumption varied from 0.10 to $21.5 \mathrm{~g}$ (mean was $10.36 \pm 7.13 \mathrm{~g}$ ). This consumption was $4.35 \%$ in relation to the mean weight of Checkered Keelback snake (Table 2). 
In winter, 07 food items were identified from 13 stomach contents. The weight of stomach contents was $83.20 \mathrm{~g}$ and the mean weight of the snakes was $219.61 \pm 102.38 \mathrm{~g}$. Of the food items Melanoplus sp. was common and found in $11(84.61 \%)$ stomachs. The food consumption varied from 0.2 to $9.0 \mathrm{~g}$ (mean 6.4 $\pm 2.63 \mathrm{~g})$. The food consumption was $2.91 \%$ in relation to the mean body weight of the snake. There was no significant difference of food consumption in different seasons of the year $\left(\chi^{2}=38.52, \mathrm{df}=2\right.$ and $\mathrm{p}<0.05$, Table 2$)$.

Table 2. Food habit of Checkered Keelback in different seasons studied in nature

\begin{tabular}{lcccccc}
\hline $\begin{array}{l}\text { Study } \\
\text { period }\end{array}$ & $\begin{array}{c}\text { Sample } \\
(\mathrm{n}=50)\end{array}$ & $\begin{array}{c}\text { Wt. of } \\
\text { stomach } \\
\text { contents }\end{array}$ & \multicolumn{2}{c}{$\begin{array}{c}\text { Food consumption } \\
\text { per individuals }\end{array}$} & $\begin{array}{c}\text { Mean wt. of } \\
\text { Checkered Keelback } \\
\text { watersnake }(\mathrm{g})\end{array}$ \\
& & $(\mathrm{g})$ & Range (g) & Mean \pm Sd & $\%$ to body wt. & \\
$\begin{array}{l}\text { Summer } \\
\text { (Mar.- Jun.) }\end{array}$ & 09 & 141.9 & $1.3-23.0$ & $15.77 \pm 6.73$ & 6.51 & $242.22 \pm 54.83$ \\
$\begin{array}{l}\text { Rainy } \\
\text { (Jul. - Oct.) }\end{array}$ & 18 & 186.4 & $0.1-21.5$ & $10.36 \pm 7.13$ & 4.35 & $238.05 \pm 13.78$ \\
$\begin{array}{l}\text { Winter } \\
\text { (Nov.-Feb.) }\end{array}$ & 13 & 83.20 & $0.2-9.0$ & $6.4 \pm 2.63$ & 2.91 & $219.61 \pm 102.38$ \\
\hline
\end{tabular}

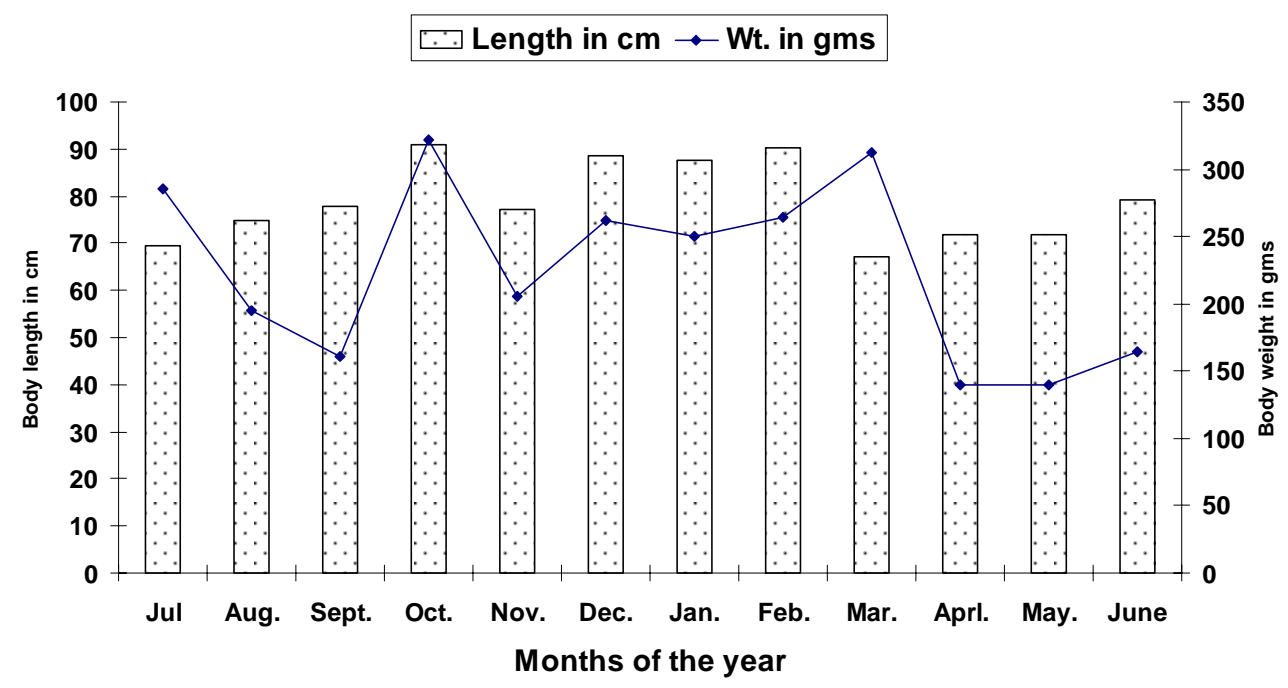

Fig. 3. Relationship between body weight and length of Checkered Keelback.

On the basis of the analysis of stomach contents it was found that the most preferred food items were grasshopper, beetles, water creeping bugs, spiders, butterflies, frogs, small fishes (Table 1).

Insects were represented by Orthoptera, Hemiptera, Coloeptera, Lepidoptera and Odonata. These 5 orders of arthropods were almost common in the food 
contents throughout the year (Fig. 4). Among orthropteran grasshopper, Melanoplus differntialis was found throughout the year. Order Hemiptera was represented by the creeping water bug, Pelocoris femoratus found only in 15 stomachs (Table 1).

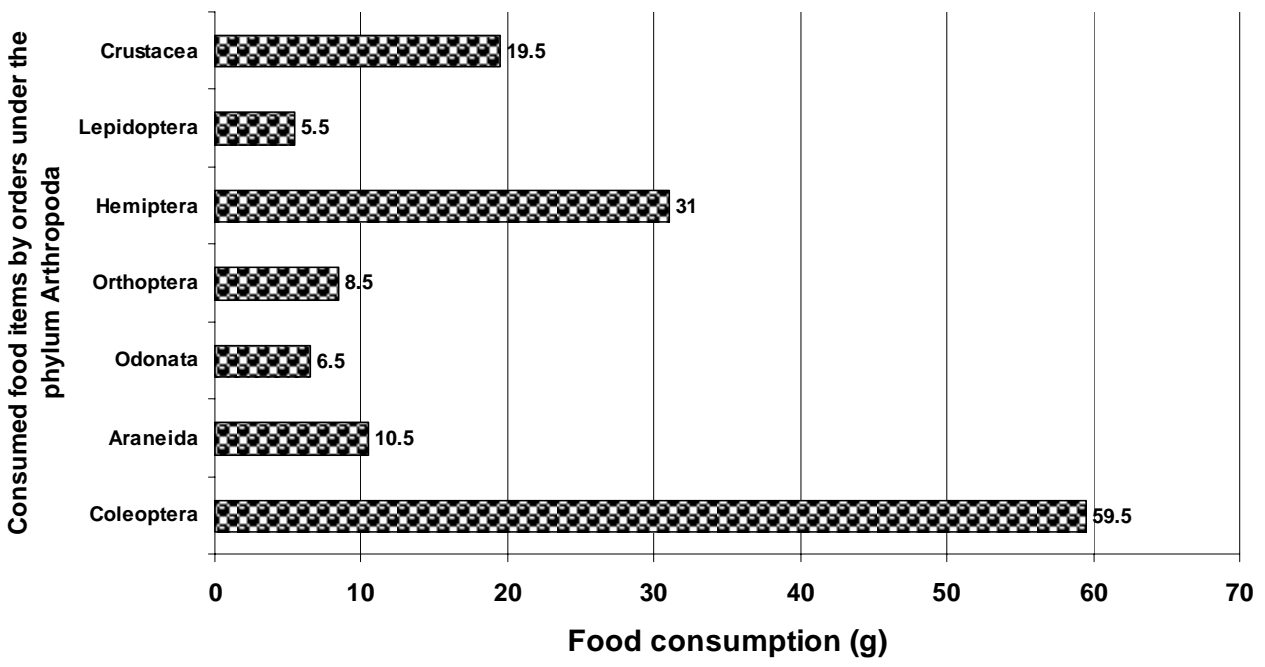

Fig. 4. Arthropod food items consumped by Checkered Keelback.

Checkered Keelback is a common species of non-venomous snake found in Asia. In the present study almost all the specimens were collected from aquatic and semi-aquatic habitats like lowland ponds, streams and ditches in cultivated fields. They are occasionally found in upland basins. Checkered Keelback needs a moist environment to prevent its highly sensitive skin from drying out and they live in ditches along the road side, streams and in stagnant water of the paddy fields. The snake is mainly aquatic, inhabiting mostly freshwater wetlands but uncommon in forested areas and coastal regions (Fugler 1982). It is mostly solitary and mainly nocturnal; inhabiting holes and bushes near permanent water courses and pools (Dutta and Mohanty 1976).

It was found that the snake as animal feeders and fed on invertebrate and small vertebrate animals. Of the stomach contents insects constituted $34.30 \%$ which represented six orders (Table 1). In the present study it was found that the average food consumption of the species was $10.28 \pm 6.78 \mathrm{~g}$ that was $4.41 \%$ of the body weight whereas Raj (2005) mentioned that insect food constituted (73.1\%) of the foods of Checkered Keelback. McCann (1933) reported that the non-poisonous snakes should be considered as natural controlling agents of animals harmful to agriculture. Orthopteran species were more or less regular food items. Rao and Cherian (1940) noted that Checkered Keelback attacked the nymphs of grasshoppers in the rice field and thus acted as one of the natural 
controlling agents of rice grasshoppers. Issac and Rege (1975) reported that Checkered Keelback feed on Colepterans and found in the stomachs throughout the year. Hemipteran were found in all the three seasons of the year and was maximum in the month of June and December (Wadekar 1963).

It is seemed that Coleoptera was one of the most preferred food items of the snake. Fugler (1982) stated that coleopterans were found in the stomach of Checkered Keelback. In the present study it was observed that the snake consumed a climbing perch, Anabus testudinus, that is a good agreement with the findings of Joshee (1986), Issac and Rege (1975). Young bull frog was found in the diet of snales (Wadekar 1963). Tadpoles of Bufo and Rana sp. were noted by Issac and Rege (1975) and Joshee (1986) in the stomachs of snakes.

Earlier studies reported that the consumption of food varied seasonally, being much less in winter than in summer and in monsoon. This finding is good agreement with the present study, but the per cent frequency occurrence of insects in relation to the total number of foods was more or less the same in all seasons. At the end of winter, consumption was much higher than during the rest of winter. Of the food contents of 40 stomachs insects belonged to 15 family and 6 orders, most of which are harmful to agriculture, forestry, gardens and houses.

Raj et al. (2005) found that non-poisonous snakes are primarily relied upon coleopteran, hemiptera, mollusca, Checkered Keelback mostly depended upon orthoptera. Most of those insects are notorious agricultural pests. Therefore, the findings of the study strongly support the beneficial role in agro-ecosystem. Checkered Keelback feeds on a great variety of insects, young frogs. Vegetable matter and several odd objects were recorded from its stomach and Khan (1973) also made similar reports.

Acknowledgements: The author gratefully acknowledges the help of Prof. Dr. Sufia Bulbul, Dr. Sharifa Sultana and Ms. Luna Sharmin, Department of Zoology, Dhaka College, for identifying the insects during the study period.

\section{LITERATURE CITED}

AHSAN, M.F. 1983. Study of food items. Stomach analysis of the Checkered Keelback snake, $X$. piscator in Bangladesh. Fisheries Information Bull. 1: 52-65.

BORROR, D.J. and DELONG, D.M. 1954. An Introduction to the Study of Insects. Holt Rinehart and Winston, United States of America, Library of Congress. $1030+$ ix pp.

BOULENGER, G.A. 1890. Fauna of British India. Reptilia and Batrachia.

DANIEL, J.C. 1983. The Book of Indian Reptiles. Bombay Nat. Hist, Soc., Bombay, India. 141 pp.

DUTTA, S.K. and MOHANTY H.P. 1976. Breeding and Life history of Checkered Keelback Snake. Utkal Univ. J. Sci. 13(1\&2): 53-59.

FUGLER, C.M. 1982. The status of population of Hoplobatrachus tigrinus Daudin in Bangladesh. Fisheries Information Bull. 1: 1-51. 
HARTLEY, P.H.T. 1948. The assessment of the food of birds. Ibis 90: 361-381.

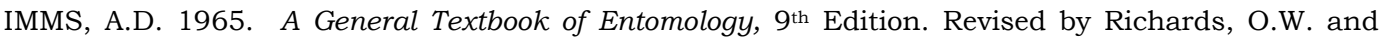
Devies, R.G. Butler and Tanner. London. 886 pp.

JOSHEE, A.K. 1986. Food habits of the Checkeed Keelback water snake (Xenochrophis piscator). J. Bombay Nat. Hist. Soc. 5: 498-501.

KEHIMKER, I. and REGE, M.S. 1975. Food of X. piscator. J. Bombay Nat. Hist. Soc. 72 : 157.

KHAN, M.S. 1973. Food of the Checkered Keelback water snake, Xenochrophis piscator (Scineider, 1799. Biologia (Lahore) 19: 93-107.

KHAN, M.A.R. 1992. Bangladesher Sap (in Bangla). Bangla Academy, Dhaka, Bangladesh. 227 pp.

McCANN, D. 1933. Notes on Indian batrachians. J. Bombay Nat. Hist. Soc. 36: 161.

POUGH, F.H., ANDREWS, R.M., CADLE, J.E., CRUMP, M.L., SAVITZKY, A.H. and WELLS, K.D. 2001. Foraging ecology and interspecific interactions. In: Herpt. $2^{\text {nd }}$ edition New Jersey : Pretice Hall. pp. 431-464.

RAJ, Y.P., BUDHA, P.B. and SHAH, K.B. 2005. Food habits of Xenochrophis piscator (Schneider, 1799), Limnonectes nepalensis (Dubois, 1975) and Bufo stomaticus Lũtken, 1862 (Amphibia: Anura) in Pokhara Valley. J. Nat. Hist. Mus. 22: 134-139.

RAO, Y.R. and CHERIAN, M.G. 1940. Control of the rice grasshoppers, Indian Farming. J. Bombay Nat. Hist. 1: 433-436.

SANIL, G. and ANDREWS, M.I. 1995. Food and feeding habits of X. piscator. J. Bombay Nat. Hist. Soc. 92: 220-224.

WADEKER, D.L. 1963. The diet of Checkered Keelback snake (Xenochrophis piscator). J. Bombay Nat. Hist. Soc. 60: 263-268. 